\title{
PROBLEMATIKA DAN LAYANAN GURU BIMBINGAN DAN KONSELING
}

\author{
Ahmad Arifai \\ Sekolah Tinggi Ilmu Tarbiyah Raudhatul Ulum Sakatiga \\ Email: sugrhu@gmail.com
}

\begin{abstract}
Abstrak
Guru adalah seorang yang melaksanakan bimbingan artinya seorang guru hendaknya melaksanakan binaan terhadap anak didiknya secara berkesinambungan, menjalin kerja sama antara guru bimbingan dan konseling dengan guru-guru yang lainnya seperti guru bidang studi, wali kelas, wakasis, TU (tata usaha), kepala sekolah. Adapun tujuan bimbingan dan konseling salah satunya layanan orientasi adalah layanan yang dilakukan unuk memperkenalkan siswa baru atau seseorang terhadap lingkungan yang baru dimasukinya. Layanan informasi bersamaan dengan layanan orientasi bermaksud memberikan pemahaman kepada individu-individu yang berkepentingan tentang berbagai hal yang diperlukan untuk menjalani suatu tugas atau kegiatan, atau untuk menentukan arah suatu tujuan atau rencana yang dikehendaki. Namun layanan guru bimbingan dan konseling dalam prosesnya masih banyak terdapat masalah-masalah dalam penerapannya seperti guru bimbingan dan konseling hanya pelengkap kegiatan, guru bimbingan dan konseling adalah "polisi sekolah", bimbingan dan konseling hanya dilakukan pada siswa tertentu saja.
\end{abstract}

Kata Kunci: Bimbingan, Konseling, Siswa

\section{Pendahuluan}

Menurut PP No.29/1990 tentang Pendidikan Menengah, pada BAB X mengenai bimbingan pasal 27 ayat 1 : bimbingan merupakan bantuan yang diberikan kepada siswa dalam rangka upaya menemukan pribadi, mengenal lingkungan dan merencanakan masa depan. Pada ayat 2 : bimbingan diberikan oleh guru pembimbing.( Prayitno, 2001:5)

Bimbingan sesuai pasal 27 di atas bertujuan untuk membantu peserta didik dalam menemukan pribadi, mengenal lingkungan serta merencanakan masa depan. Jadi dengan adanya bimbingan peserta didik akan tahu bagaimana mereka mengenali pribadi mereka, lingkungan sosial, yang tidak lain adalah lingkungan interaksi mereka dalam kehidupan sehari-hari baik keluarga sekolah atau masyarakat. Bimbingan juga dapat membantu menentukan masa depan awalnya peserta didik bimbang untuk menentukan dimana mereka akan melanjutkan kejenjang berikutnya namun dengan adanya bimbingan peserta didik akan mendapat gambaran dalam menentukan masa depannya. Sedangkan pada ayat 2 di atas dijelaskan guru adalah seorang yang melaksanakan bimbingan artinya seorang guru hendaknya melaksanakan binaan terhadap anak didiknya secara 


\section{Problematika Dan Layanan Guru Bimbingan Konseling Ahmad Arifai}

berkesinambungan supaya tahu masalah apa yang menjadi penghambat mereka dalam mengikuti proses pembelajaran.

\section{Pembahasan}

\section{Pengertian Bimbingan dan Konseling}

Bimbingan merupakan " helping" yang identik dengan "aiding assisting, atau availing," yang berarti bantuan atau pertolongan makna pertolongan dalam bimbingan menunjukkan bahwa yang aktif dalam mengembangkan diri, mengatasi masalah atau mengambil keputusan adalah individu atau peserta didik sendiri. Dalam proses bimbingan pembimbing tidak memaksakan kehendaknya sendiri, tetapi berperan sebagi fasilitator. Istilah bantuan dalam bimbingan dapat juga dimaknai sebagai upaya untuk (a) menciptakan lingkungan (fisik, psikis, sosial dan spiritual) yang kondusif bagi perkembangan peserta didik, (b) memberikan dorongan dan semangat, (c) mengembangkan keberanian bertindak dan bertanggung jawab dan (d) mengembangkan kemampuan untuk memperbaiki dan mengubah prilakunya sendiri. sedangkan konseling adalah hubungan tatap muka yang bersifat rahasia penuh dengan sikap penerimaan dan pemberian kesempatan dari konselor kepada klien, konselor mempergunakan pengetahuan keterampilannya untuk membantu kliennya mengatasi masalah-masalahnya. (Syamsu Yusuf, 2010:1)

Selain pengertian di atas bimbingan merupakan bantuan yang diberikan kepada individu (seorang) atau kelompok (sekelompok orang) agar mereka itu dapat mandiri melalui berbagai bahan, interaksi, nasihat, gagasan, alat dan usaha yang berdasarkan norma-norma yang berlaku. bimbingan dapat diartikan sebagai bentuk bantuan yang diberikan kepada peserta didik agar dapat mempersiapkan diri dalam mengambil sebuah karir yang akan berguna bagi masa depan peserta didik. Pengertian lain bimbingan adalah bantuan atau pertolongan yang diberikan kepada individu atau sekumpulan individu-individu dalam menghindari atau mengatasi kesulitan-kesulitan di dalam kehidupannya, agar individu atau sekumpulan individu-individu itu dapat mencapai kesejahteraan hidupnya.

\section{Landasan-Landasan Bimbingan dan Konseling \\ a. Landasan filosofi}

John J. Pietrofesa mengemukakan terdapat beberapa prinsip yang terkait dengan landasan filosofis dalam bimbingan yaitu. Pertama, objective viewing dalam hal ini konselor membantu klien agar memperoleh suatu prespektif tentang masalah khusus yang dialaminya, dan membantunya untuk menilai atau mengkaji berbagai alternatif atau strategi kegiatan yang memungkinkan klien mampu merespon interes, minat, atau keinginannya secara konstruktif. Kedua, the counselor must have the best interest of the clien at heart. Dalam hal ini konselor harus merasa puas dalam membantu klien mengatasi maslahnya.

b. Landasan Sosial Budaya \& Religius 
Masalah lain sebagai dampak negatif dari kehidupan ini adalah semakin kompleknya jenis-jenis dan syarat-syarat pekerjaan. Jenis dan pola kehidupan, jenis dan kesempatan pendidikan, persaingan antar individu dan sebagainya. Dengan demikian individu dituntut untuk lebih mampu menghadapi berbagai masalah seperti masalah penyesuaian diri, masalah pemilihan pekerjaan, masalah perencanaan dan pemilihan pendidikan, masalah-masalah hubungan sosial, masalah keluarga, masalah keuangan, dan masalah pribadi. Sekolah tidak dapat melepaskan diri dari situasi kehidupan masyarakat, dan mempunyai tanggung jawab untuk membantu peserta didik baik sebagai pribadi atau sebagai calon anggota masyarakat. (Syamsu Yusuf, 2010:1)

Landasan layanan bimbingan dan konseling juga perlu ditekankan pada tiga hal pokok, yaitu: pertama, keyakinan bahwa manusia dan seluruh alam semesta adalah mahluk Tuhan. Kedua sikap yang mendorong perkembangan dan perikehidupan manusia berjalan ke arah positif dan sesuai dengan kaidah-kaidah agama dan upaya yang memungkinkan berkembang dan dimanfaatkannya secara optimal suasana dan perangkat budaya (termasuk ilmu pengetahuan dan teknologi) serta pemasyarakatan yang sesuai dan meneguhkan kehidupan beragama untuk membantu perkembangan dan pemecahan individu. (Prayitno, 2004:146)

c. Landasan Psikologi

Beberapa aspek psikologi dan faktor yang mempengaruhi perkembangan pribadi yang perlu dipahami oleh konselor yaitu motif yang merupakan salah satu aspek psikis yang penting diketahui karena keberadaannya sangat berperan dalam tingkah laku individu. Pada dasarnya tidak ada tingkah laku yang tanpa motif. Motif adalah energi dasar yang mendorong tingkah laku individu.

\section{Layanan dan Pondasi Bimbingan dan Konseling}

Terdapat beberapa layanan yang dilaksanakan dalam bimbingan dan konseling yaitu:

a) Layanan pengumpulan data, dalam layanan ini semua data tentang individu beserta latar belakangnya dihimpun dan didokumentasikan, data dihimpun dari berbagai sumber dengan menggunakan angket, wawancara, observasi, studi dokumenter dan tes. Data yang dihimpun diantaranya data pribadi, keluarga, sosial, budaya, agama, status ekonomi, prestasi, kecerdasan intelektual, kecerdasan emosional, kecerdasan spiritual, ketekunan dan sebagainya.

b) Layanan informasi layanan memberi informasi yang di butuhkan oleh individu. Tujuan layanan ini adalah agar individu memiliki pengetahuan (informasi) yang memadai, baik tentang dirinya maupun tentang lingkungannya.

c) Layanan penempatan layanan untuk membantu individu dalam memperoleh tempat bagi pengembangan potensi yang dimilikinya. Tujuan layana ini adalah agar setiap individu dapat mengembangkan diri secara optimal sesuai dengan potensi dan kekuatan yang dimilikinya. 


\section{Problematika Dan Layanan Guru Bimbingan Konseling \\ Ahmad Arifai}

d) Layanan konseling merupakan layanan untuk membantu individu menyelesaikan masalah-masalah terutama masalah sosial pribadi yang mereka hadapi.

e) Layanan referal layanan untuk melimpahkan masalah yang dihadapi individu kepada pihak lain yang lebih mampu dan berwewenang, apabila masalah yang ditangani pembimbing di luar kemampuan dan kewenangan personal pemberi bantuan yang ada.

f) Layanan evaluasi dan tindak lanjut untuk menilai pelaksanaan dan keberhasilan layanan bimbingan yang diberikan, diadakan evaluasi. Berdasarkan hasil evaluasi tersebut diadakan upaya-upaya tindak lanjut untuk menyempurnakannya. Layanan evaluasi ini menyangkut evaluasi proses ataupun evaluasi hasil pelaksanaan bimbingan dan konseling.( Achmad Juntika, 2009:19)

Selain layanan di atas ada penjelasan lain mengenai jenis layanan bimbingan dan konseling yaitu: layanan orientasi adalah layanan yang dilakukan unuk memperkenalkan siswa baru atau seseorang terhadap lingkungan yang baru dimasukinya. Layanan informasi bersamaan dengan layanan orientasi bermaksud memberikan pemahaman kepada individu-individu yang berkepentingan tentang berbagai hal yang diperlukan untuk menjalani suatu tugas atau kegiatan, atau untuk menentukan arah suatu tujuan atau rencana yang dikehendaki. Dan layanan informasi juga merupakan suatu layanan yang berupaya memenuhi kekurangan individu akan informasi yang mereka perlukan. Layanan informasi juga bermakna usaha-usaha untuk membekali peserta didik dengan pengetahuan serta pemahaman tentang lingkungan hidupnya dan tentang proses perkembangan anak muda.(Tohirin 2011:147)

Tujuan layanan informasi agar individu mengetahui menguasai informasi yang selanjutnya dimanfaatkan untuk keperluan hidupnya sehari-hari dan perkembangan dirinya. Selain itu apabila merujuk kepada fungsi pemahaman, layanan informasi bertujuan agar individu memahami berbagai informasi dengan segala seluk beluknya. Penguasaan akan berbagai informasi dapat digunakan untuk mencegah timbulnya masalah, pemecahan suatu masalah, untuk memelihara dan mengembangkan potensi individu serta memungkinkan individu yang bersangkutan membuka diri dalam mengaktualisasikan hak-haknya.

Layanan informasi juga bertujuan untuk mengembangkan kemandirian. Pemahaman dan penguasaan individu terhadap informasi yang diperlukannya akan memungkinkan individu: (a) mampu memahami dan menerima diri dan lingkungannya secara objektif, positif, dan dinamis, (b) mengambil keputusan, (c) mengarahkan diri untuk kegiatan-kegiatan yang berguna sesuai dengan keputusan yang diambil dan (d) mengaktualisasikan secara terintegrasi.

Terdapat beberapa prinsip dasar yang dipandang sebagai pondasi atau landasan bagi layanan bimbingan. Prinsip-prinsip ini berasal dari konsep-konsep filosofis tentang kemanusiaan yang menjadi dasar bagi pemberian layanan bantuan atau bimbingan, baik di sekolah maupun diluar sekolah. Prinsip-prinsip bimbingan dan konseling adalah sebagai berikut: 
1) Bimbingan diperuntukkan bagi semua individu (guidance is for all indivduals). Prinsip ini berarti bahwa bimbingan diberikan kepada semua individu atau peserta didik, baik yang tidak bermasalah, baik pria ataupun wanita, baik anak-anak, remaja maupun dewasa.

2) Bimbingan bersifat individualisasi. Setiap individu bersifat unik, dan melalui bimbingan individu dibantu untuk memaksimalkan perkembangan keunikannya tersebut.

3) Bimbingan menekankan hal yang positif. Dalam kenyataan masih ada individu yang memiliki persepsi yang negatif terhadap bimbingan, karena bimbingan dipandang sebagai satu cara yang menekan aspirasi. Sangat berbeda dengan pandangan tersebut, bimbingan sebenarnya merupakan proses bantuan yang menekankan kekuatan dan kesuksesan, karena bimbingan merupakan cara untuk membangun pandangan yang positif terhadap diri sendiri, memberikan dorongan dan peluang untuk berkembang.

4) Bimbingan merupakan usaha bersama. Bimbingan bukan hanya tugas atau tanggung jawab konselor, tetapi juga tugas guru-guru dan kepala sekolah.

5) Pengambilan keputusan merupakan hal yang esensial dalam bimbingan. Bimbingan diarahkan untuk membantu individu agar dapat melakukan pilihan dan mengambil keputusan.

6) Bimbingan berlangsung dalam berbagai setting (adegan) kehidupan. Pemberian layanan bimbingan tidak hanya berlangsung di sekolah, tetapi juga dikalangan keluarga, perusahaan/industri, lembaga-lembaga pemerintah/swasta dan masyarakat pada umumnya.

\section{Prolematika Pelaksanaan Bimbingan dan Konseling}

Problematika utama dalam pelaksanaan BK di dunia pendidikan juga disebabkan adanya kekeliruan -kekeliruan pandangan. Berikut ini kekeliruan-keliruan tersebut.

a. Bimbingan dan konseling hanya pelengkap kegiatan pendidikan

Ada sebagian orang yang berpendapat bahwa bimbingan dan konseling hanyalah pelengkap dalam dunia pendidikan sehingga sekolah tidak perlu lagi bersusah payah menyelenggarakan pelayanaan bimbingan dan konseling, karena dianggap sudah implisit dalam pendidikan itu sendiri. Cukup mantapkan saja pengajaran sebagai pelaksanaan nyata dari pendidikan. Mereka sama sekali tidak melihat arti penting bimbingan dan konseling di sekolah. Kendati begitu, bukan berarti BK dan pendidikan harus terpisah. Pada hakikatnya, dua unsur ini saling membutuhkan dan saling melengkapi bimbingan dan konseling memiliki derajat dan tujuan yang sama dengan pelayanan pendidikan, yaitu mengantarkan para siswa untuk memperoleh perkembangan diri yang optimal. Perbedaanya hanya terletak dalam pelaksanaan tugas dan fungsinya, yang masing-masing memiliki karakteristik tugas, dan fungsi yang khas dan berbeda.

b. Guru bimbingan dan konseling di sekolah adalah "polisi sekolah" 


\section{Problematika Dan Layanan Guru Bimbingan Konseling}

Ahmad Arifai

Masih banyak anggapan bahwa bimbingan dan konseling adalah "polisi sekolah". Hal ini disebabkan pihak sekolah sering menyerahkan sepenuhnya masalah pelanggaran kedisiplinan dan peraturan sekolah lainnya kepada guru BK. Bahkan, banyak guru BK yang diberi wewenang sebagai eksekutor bagi siswa yang bermasalah. Dengan demikian, banyak sekali ditemukan disekolah-sekolah yang menganggap guru BK sebagai guru "killer" (yang ditakuti).

c. Bimbingan dan konseling dibatasi hanya untuk siswa tertentu saja. Bimbingan dan konseling tidak hanya diperuntukkan bagi siswa yang bermasalah atau siswa yang memiliki kelebihan tertentu saja, namun bimbingan dan konseling harus melayani seluruh siswa (guidance and counseling for all). Semua siswa berhak dan mendapat kesempatan pelayanan yang sama, melalui berbagai bentuk pelayanaan bimbingan dan konseling yang tersedia.(Anas, 2002:229)

\section{Karakteristik Guru Bimbingan dan Konseling atau Konselor}

Setiap bidang pasti memiliki karakter dalam pelaksanannya baik dari personilnya maupun hal lain. Seperti halnya bimbingan dan konseling memiliki ciri untuk menentukan pribadi yang bisa dijadikan sebagai guru bimbingan dan konseling di antaranya:

a. Beriman dan bertaqwa kepada Tuhan Yang Maha Esa. Ciri ini hendakanya tampil dalam prilaku keseharian seorang konselor dalam memperlakukan klien, dan dalam pengambilan keputusan ketika merancang pendekatan yang akan dipergunakan.

b. Berpandangan positif dan dinamis tentang manusia sebagai mahluk spiritual, individual dan sosial. Konselor hendaknya memandang klien bukan sebagai mahluk yang dapat diperlakukan semena-mena sesuai rasa senang konselor.

c. Menghargai harkat dan martabat manusia dan hak asasi manusinya, serta bersikap demokratis.

d. Menampilkan nilai, norma dan moral yang berlaku dan berahlak mulia.

e. Menampilkan integritas dan stabilitas kepribadian dan kematangan emosional. Seorang konselor hendaknya memiliki kepribadian yang utuh, sehingga ia tidak mudah terpengaruh oleh suasana yang timbul pada saat konseling.

f. Cerdas kreatif dan mandiri dan berpenampilan menarik. Ciri ini sangat diperlukan oleh seorang konselor, sebab ia harus dapat mengambil keputusan tentang tindakan apa yang seharusnya dilakukan dalam menghadapi klien yang seperti apapun kondisinya.( Supriatna, 2011:22)

\section{Simpulan}

Guru adalah seorang yang melaksanakan bimbingan artinya seorang guru hendaknya melaksanakan binaan terhadap anak didiknya secara berkesinambungan, menjalin kerja sama antara guru bimbingan dan konseling dengan guru-guru yang lainnya seperti guru bidang studi, wali kelas, wakasis, TU (tata usaha), kepala sekolah. Guru bimbingan dan konseling sebagai polisi sekolah adalah dengan memberikan 
RAUDHAH Proud To Be Professionals Jurnal Tarbiyah)damiyah

Volume 1 Nomor 1 Edisi Juni 2016

P-ISSN : 2541-3686

arahan, pengertian, penjelasan kepada siswa bahwa guru bimbingan dan konseling tidak harus ditakuti, dan memberi tahu siswa akan manfaat ruangan bimbingan dan konseling. Semua siswa berhak dan mendapat kesempatan pelayanan yang sama, melalui berbagai bentuk pelayanaan bimbingan dan konseling yang tersedia. Setiap bidang pasti memiliki karakter dalam pelaksanannya baik dari personilnya maupun hal lain. Seperti halnya bimbingan dan konseling memiliki ciri untuk menentukan pribadi yang bisa dijadikan sebagai guru bimbingan dan konseling

\section{DAFTAR PUSTAKA}

Prayitno, Panduan Pengawasan Bimbingan dan Konsling di Sekolah, Jakarta: PT Rineka Cipta, 2001

Syamsu Yusuf dan Juntika Nurihsan, Landasan Bimbingan dan Konseling, Bandung: Remaja Rosdakarya,

Mamat Supriatna, Bimbingan dan Konseling Berbasis Kompetensi, Jakarta: Rajawali Press, 2011

Achmad Juntika Nurihsan, Bimbingan dan Konseling Dari Berbagai Latar Kehidupan, Bandung: Refika Aditama, 2009

Prayitno dan Erman Amti, Dasar-dasar Bimbingan dan Konseling, Jakarta: Rineka Cipta, 2009

Tohirin, Bimbingan dan Konseling di Sekolah dan Madrasah, Jakarta: Rajawali Pres, 2011 